\title{
Anti-Proliferative Activity of Nigella sativa Chloroform Extract on 7, I 2-Dimethylbenz[a] anthracene Induced Female Rats Splenocyte
}

\author{
Ahmad Fiki Firdaus, Iskandar Sobri, Heny Ekowati* \\ Pharmacy Department, Faculty of Medicine and Health Sciences, Universitas Jenderal Soedirman, \\ Dr. Soeparno Street, Karangwangkal, Purwokerto 53123 \\ Phone. +62-281-642840, Purwokerto, Indonesia, e-mail: heny240377@gmail.com
}

\begin{abstract}
Previous study reported that Nigella sativa has in vitro and in vivo cancer activity. This study was conducted to observe the effect of chloroform extract of Nigella sativa seed (NCE) on 7,12-Dimethylbenz[a]anthracene (DMBA)-induced female rats' splenocyte. The experiment consisted of five groups, corn oil solvent control group, DMBA group, $\mathrm{DMBA}+250 \mathrm{mg} / \mathrm{kgBW} \mathrm{NCE}, \mathrm{DMBA}+500 \mathrm{mg} / \mathrm{kgBW} \mathrm{NCE}$ and DMBA+750 mg/kgBW NCE. Extract was dissolved in corn oil and oral administered daily for 2 weeks before and during the DMBA induction. Observation of cell proliferation was performed using haematoxylin and eosin (H\&E) and AgNOR stainings. H\&E staining showed decreased necrocis activity extract groups compared to DMBA group. From AgNOR staining results, mean AgNOR (mAgNOR) of extract groups was less in number compared to DMBA group. The mAgNOR in corn oil solvent control group, DMBA group, DMBA+250 mg/kgBW NCE, DMBA +500 $\mathrm{mg} / \mathrm{kgBW} \mathrm{NCE}$ and DMBA+750 mg/kgBW NCE were I.22, I.91, I.29, 1.36 and I.33, respectively. Our current results showed that NCE reduces the proliferation of DMBAinduced rat spleenocytes Thus, NCE has potency to be developed as a chemopreventive agent.
\end{abstract}

Keywords: Nigella sativa, spleen, DMBA, anti-proliferative

\section{INTRODUCTION}

Malignant lymphocytes can grow in various lymphoid organs in the body. One of the lymphoid organs is spleen which is the largest lymphoid organ in the organism. One of the carcinogenic substances that caused cancer is 7,12-Dimethylbenz $[a]$ anthracene (DMBA). DMBA is metabolized by cytochrome P450 enzymes. DMBA will react with DNA to initiate cancer. DMBA caused normal cells in the spleen to change into lymphoblastic cell (Gao, et al., 2007).

Chemotherapy and radiotherapy have been developed to treat cancer. These treatment methods cause a lot of side effects, including hair loss, feeling or being sick, feeling tired, and having low levels of blood cells (ACS, 2010). Therefore, we need to search for new ingredients which can be used safely by patients to inhibit cancer proliferation. Herbal plants have been studied to prevent and to treat diseases. One of the herbal plants is black cumin (Nigella sativa).

Compounds of N.sativa which have antiproliverative activity are palmitoic acid, stearric acid, oleic acid and linoleic acid (Syazana, et al., 2011). The gas chromatography mass spectrometry (GCMS) showed that chloroform extract of $N$.sativa contained $95.5 \%$ fatty acids which the main component fats are linoleic acid $(55.6 \%)$, oleic acid $(23.4 \%)$ and palmitoic acid (12.5\%) (Ekowati, et al., 2011).

\footnotetext{
$\overline{\text { *Corresponding author e-mail: heny240377@gmail.com }}$
} 
Based on previous studies, chloroform extract of N.sativa (NCE) has in vitro anticancer activity on T47D and MCF-7 breast cancer cells, HeLa cells, and WiDr colon cancer cells. This study was conducted to examine the effect of NCE in inhibiting the proliferation of malignant lymphocytes in spleen induced by DMBA.

\section{MATERIALS AND METHODS}

\section{Materials}

$N$. sativa seed was oven-dried at temperature of $50 \pm 1{ }^{\circ} \mathrm{C}$. The powder was extracted by maceration technique using petroleum ether for $1 \times 24$ hours and continued using chloroform for $3 \times 24$ hours. DMBA was obtained from Sigma (Saint Louis, MO). DMBA and N. Sativa chloroform extract (NCE) were dissolved in corn oil.

\section{Animals}

Sprague Dawley female rats weighed $75 \pm 15 \mathrm{~g}$, were obtained from Laboratory of Pharmacology and Toxicology, Faculty of Pharmacy, Universitas Gadjah Mada, Yogyakarta, Indonesia. The rats were quarantined for at least one week.

Sixty rats were divided into five groups (12 rats per group). The experimental design is summarized in Fig.1. For solvent control (group 1), rats were administered with corn oil. Meanwhile, for treatment groups (groups 2, 3, 4 and 5), rats were induced by oral administration of $20 \mathrm{mg} / \mathrm{kgBW}$ DMBA (Sigma), twice a week, for 5 weeks, then were treated with oral administration of 0 (Group 2), 250 (Group 3), 500 (Group 4) and 750 (Group 5) mg/KgBW NCE, once a day for 6 weeks, started from 1 week before DMBA. BWs were recorded weekly.

\section{Haematoxylin \& Eosin Staining}

At the end of the experiment (16 weeks) all rats were sacrificed by decapitation. Spleens were then removed and fixed in $10 \%$ buffered formalin. After 12-24 h of fixation, tissues were embedded in paraffin, sliced with thickness of 3-5 $\mu \mathrm{M}$, mounted on glass slides, processed further for H\&E staining.

\section{AgNOR Staining}

AgNOR staining was performed according to the modified method (Pich, et al., 2003; Bankafalvi, et al., 2003). The staining solution was prepared by mixing one part of $2 \%$ gelatin in $1 \%$ formic acid with two parts of $50 \%$ aqueous silver nitrate $\left(\mathrm{AgNO}_{3}\right)$. All sections were sliced with thickness of 3 $\mu \mathrm{m}$ from routinely processed paraffin blocks. Sections were immersed in sodium citrate buffer $(\mathrm{pH}$ 6.0) and were incubated for 20 minutes in autoclave $\left(120^{\circ} \mathrm{C}, 1.1-1.2 \mathrm{Bar}\right)$.

Sections were then covered with the staining solution at room temperature in the dark for 15-20 minutes. The specimens were then washed with $5 \%$ sodium thiosulfate and distilled deionized water, dehydrated through graded ethanol to xylene, and mounted in synthetic medium. AgNORs, which appeared as dots both outside and within the nucleoli, were counted according to the description of previous report (Rizali and Auerkari, 2003).

A minimum of one hundred nuclei per specimen were observed randomly in three different views. mAgNOR is the mean of number of black dots observed in a cell, computed from total amount of blackdots (minimal 100 cells) divided with amount of cells. All specimens were observed on a binocular microscope (Olympus ${ }^{\circledR}$ DP12 microscope digital camera system, NY) with an immersion oil lens at magnification of $1000 \mathrm{x}$.

\section{Statistical Analysis}

A statistically significant BW difference was evaluated by ANOVA, continued with HSD $(p<0.05)$ between groups was considered statistically significant using SPSS (SPSS version17.0; SPSS Inc.).

\section{RESULTS AND DISCUSSION}

\section{Effect of DMBA on Female Rats BW}

There was no direct evidence of toxicity due to NCE treatment. BW changes of animals treated with corn oil, DMBA, and DMBA+NCE were shown in (Table I). In the beginning of the study, BW of corn oil group was different from other groups $(p<0.05)$. Final BW showed that DMBA group was not significant different from DMBA+NCE groups $(p<0.05)$ (Table I). 


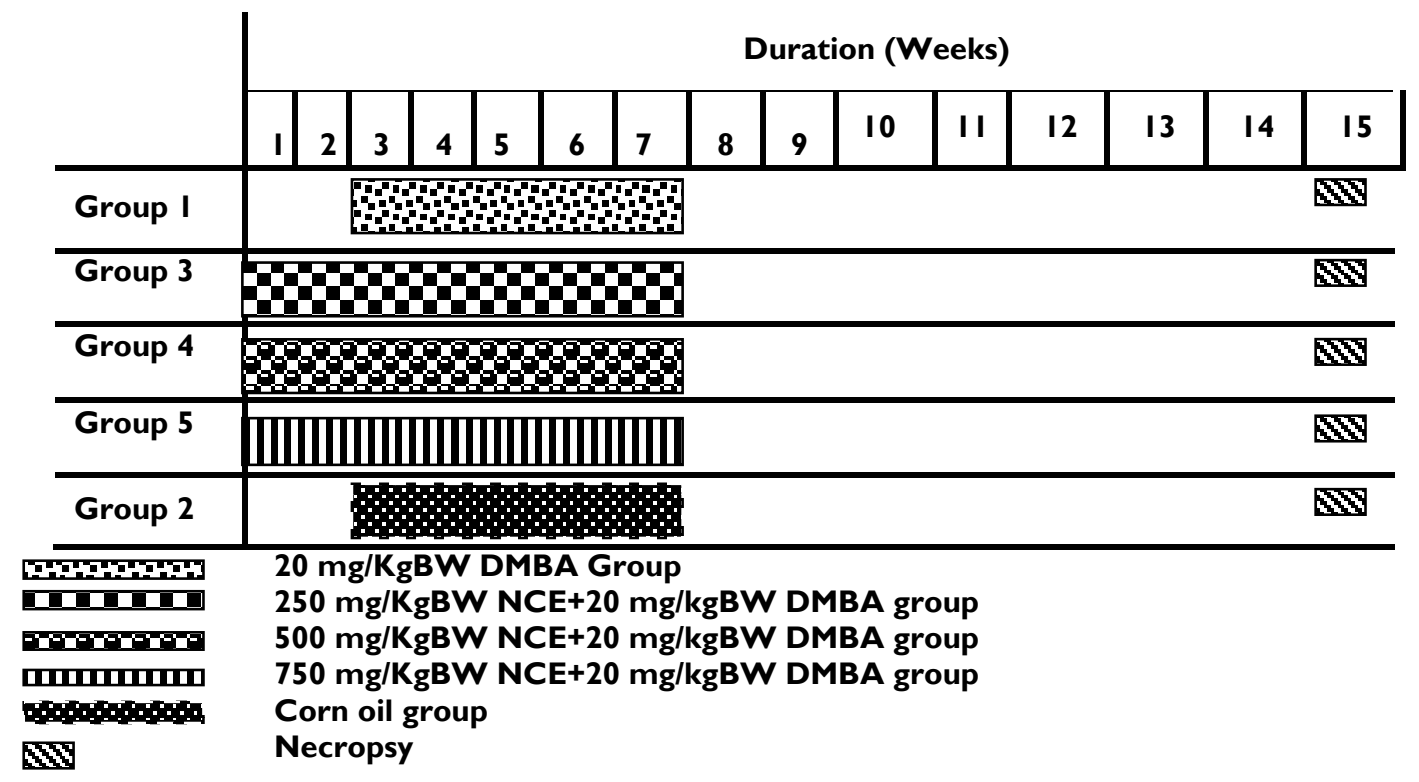

Figure I. Experimental timeline

Table I. Effect of DMBA, NCE \& Corn Oil on Rats-BW

\begin{tabular}{lcc}
\hline Group & BW & BW \\
& Before Treatment (g) & After Treatment(g) \\
\hline DMBA & $90.000 \pm 15.374$ & $121.429 \pm 68.947$ \\
DMBA + $250 \mathrm{mg} / \mathrm{Kg} \mathrm{BW} \mathrm{NCE}$ & $90.000 \pm 20.449$ & $112.000 \pm 58.98 \mathrm{I}$ \\
DMBA + 500 mg/Kg BW NCE & $78.333 \pm 17.494$ & $121.429 \pm 63.883$ \\
DMBA + 750 mg/Kg BW NCE & $64.167 \pm 15.050^{*}$ & $82.000 \pm 46.212^{*}$ \\
Corn oil & $54.167 \pm 9.003^{*}$ & $90.000 \pm 35.707^{*}$ \\
\hline
\end{tabular}

Values are expressed as mean $\pm S D ; n=12, *$ Statistical significant in comparison to DMBA group $p<0.05$ 


\section{Histopathological Studies of Spleen}

Histopathology profiles of spleen treated with DMBA and DMBA+NCE were depicted in Fig. 2. In general, H\&E staining showed no morphological differences between DMBA and $\mathrm{DMBA}+\mathrm{NCE}$-treated groups. There were only some spleens in DMBA and and DMBA+NCE groups showed necrosis cells (Fig. 2).
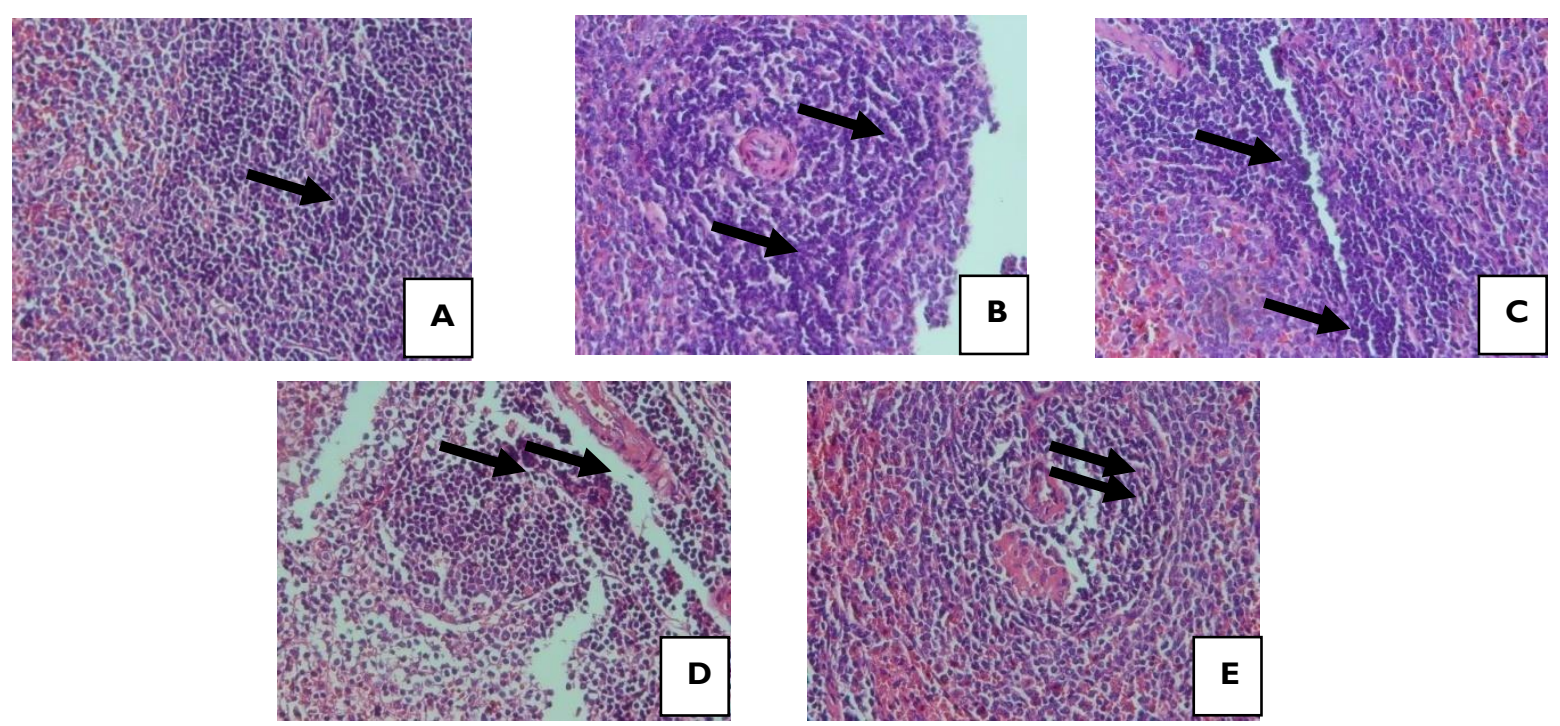

Figure 2. Histological evaluation of spleen tissues. (A) Corn oil, (B) DMBA control group, (C) DMBA+250 mg/KgBW NCE; (D) DMBA+500 mg/KgBW NCE, (E) DMBA+750 mg/KgBW NCE. Black arrow shows necrotic cell) with magnification $1000 x$

\section{Anti-Proliferative Activity of NCE}

AgNOR staining on spleen's solvent (Fig.3) showed that DMBA group has numerous blackdots than other groups. mAgNOR scores (Table II) of corn oil and DMBA are $1.22 \pm 0.12$ and $1.92 \pm 0.55$ respectively. Treatments of $250 \mathrm{mg} / \mathrm{KgBW}, 500$ $\mathrm{mg} / \mathrm{KgBW}$, and $750 \mathrm{mg} / \mathrm{KgBW}$ NCE exhibited a significant anti-proliferative activity of DMBA (Table II) with mAgNOR scores of $1.29 \pm 0.39,1.36 \pm 0.08$ and $1.33 \pm 0.11$ $(p<0.05)$. In general, treatment of NCE inhibited proliferation of DMBA-induced spleenocytes. 

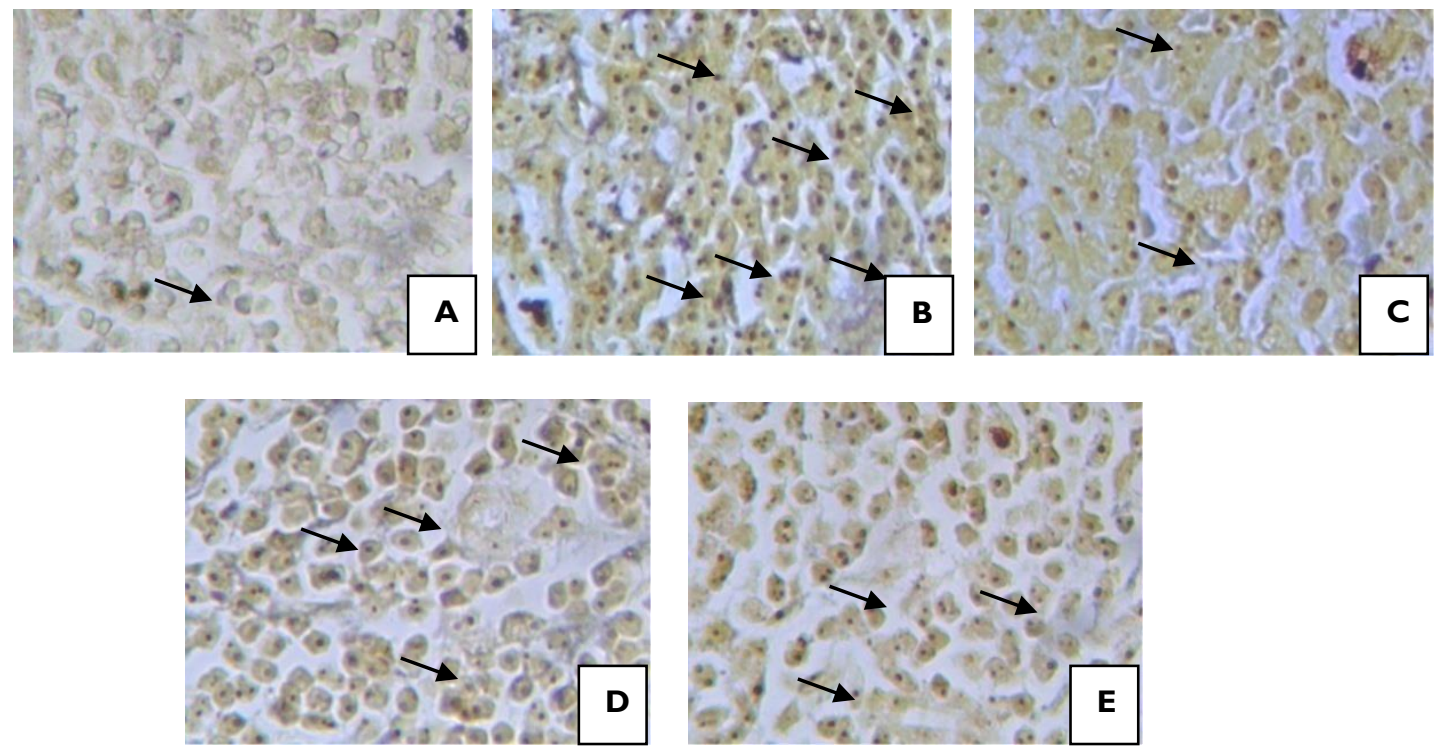

Figure 3. $\mathrm{AgNO}_{3}$ stained of spleen tissues. (A) Corn oil, (B) DMBA control group, (C) DMBA+250 $\mathrm{mg} / \mathrm{KgBW}$ NCE; (D) DMBA+500 mg/KgBW NCE, (E) DMBA+750 mg/KgBW NCE, Black arrow shows dark dots) with magnification 1000x.

Table II. Effect of NCE on proliferation of DMBA-induced rats spleenocytes

\begin{tabular}{lc}
\hline Group & mAgNOR \\
\hline DMBA & $1.916 \pm 0.551$ \\
$D M B A+250 \mathrm{mg} / \mathrm{Kg} \mathrm{BW} \mathrm{NCE}$ & $1.293 \pm 0.389^{*}$ \\
$\mathrm{DMBA}+500 \mathrm{mg} / \mathrm{Kg} \mathrm{BW} \mathrm{NCE}$ & $1.360 \pm 0.813^{*}$ \\
DMBA $+750 \mathrm{mg} / \mathrm{Kg} \mathrm{BW} \mathrm{NCE}$ & $1.333 \pm 0.107^{*}$ \\
Corn oil & $1.223 \pm 0.117^{*}$
\end{tabular}

*Statistically significant in comparison to DMBA groups $(\mathrm{p}<0.05)$ by one way Anova continued with Tukey HSD.

DMBA is one of Polycyclic Aromatic Hydrocarbons carcinogenic compounds (PAHs) metabolized by cytochrome P450 (Rajapaksa, et al., 2007). DMBA is a substrate of the enzyme cytochrome P450 (CYP), CYP1A1, and CYP1B1 (Shimada and Guengerich, 2006). In the phase I metabolism, DMBA is changed to 8.9-; 5.6-; 3,4-epoxide DMBA by CYP1A1and 3,4- epoxide DMBA by CYP1B1 (Hermawan, et al., 2011). DMBA enhances the production of reactive oxygen species (ROS). DMBA can also decrease the body's antioxidant level leading to radicals attack that cannot be neutralized by the body. It will cause cell damage and cell necrosis (Patri, et al., 2009). DMBA also increase intracellular $\mathrm{Ca}^{2+}$ which would interfere membrane permeability, increase the influx of extracellular fluid into cells, and reduce cell viability (Golstein and Kroemer, 2006). Therefore, membrane permeability will be impaired and increased intracellular fluid. Cell lysis will then be followed by the release of the contents of the cytoplasm. $N$. sativa is a plant that has antioxidant activity ability to protect the body from oxidative stress (Gilani, et al., 2004). It can be seen in treatment groups, which have less necrotic cells compared to DMBA groups.

Cellular proliferation requires an orderly progression through the cell cycle, primarily driven by protein complexes composed of cyclins and cyclin-dependent kinases (CDKs). Progression through the G1-S transition requires the activity of at-least two different types of kinases, cyclin D-Cdk4/6 and cyclin E/A-Cdk2. N.sativa decreases the expression of cyclin D1 (Aggarwal, et al., 2008) and inhibits cell proliferation, leading to cell cycle arrest (Ilairaja, et al., 2010). Treatment groups 
showed less black dots number than control (DMBA group).

Tumor cells evolve a variety of strategies to limit or circumvent apoptosis. The most common hallmark is the loss of p53 tumor suppressor function. Tumors may achieve similar ends by increasing expression of antiapoptotic regulators (Bcl-2, Bcl-xL) or survival signals (Igf1/2), by downregulating proapoptotic factors (Bax, Bim, Puma), or by short-circuiting the extrinsic ligand-induced death pathway (Hanahan and Weinberg, 2011). N.sativa stimulates apoptosis by increasing p53 expression (Yazan, et al., 2009; Ilaiyaraja and Khanum, 2010) and inhibiting anti-apoptotic proteins (Ivankovic, et al., 2006).

$N$. sativa stimulates the expression of GST (Ilaiyaraja and Khanum, 2010) which will conjugate DMBA compounds to prevent DMBA from binding with DNA, RNA,or protein (Murray, et al., 2006). GST is a phase II metabolic enzyme that detoxify carcinogens and facilitate their excretion by promoting the conjugation of electrophilic compounds with glutathione. GST deactivates and protects the surrounding tissues from mutagenesis and carcinogenesis.

Our current results showed that oral administered of NCE decreased necrosis and proliferative activity of DMBA-induced rat spleenocytes. These results indicated that NCE has a potency to be developed as a chemopreventive agent.

\section{ACKNOWLEDGEMENT}

The authors wish to express their sincere gratitude to the Directorate of Higher Education, Ministry of Education and Culture, and to Jenderal Soedirman University for financial support of this study through Competitive Research Grant 2010-2011.

\section{REFERENCES}

Aggarwal, B.B. Kunnumakkara, A.B. Harikumar, K.B. Tharakan, S.T. Sung, B. and Anand, P., 2008, Potential of SpiceDerived Phytochemicals for Cancer Prevention, Planta Med., 74, I5601569.

American Cancer Society, 2010, Non-Hodgkin Lymphoma, www.cancer.org.

Bánkfalvi, A. Giuffré, G. Öfner, D. Diallo, R. Poremba, C. Buchwalow, I.B. Barresi,
V. Böcker, W., and Tuccari, G., 2003, Relationship Between HER2 Status and Proliferation Rate in Breast Cancer Assesed by Immunohistochemistry, Fluorescence in Situ Hybridisation and Standardised AgNOR Analysis, Int. J. Oncol., 23, I285-I292.

Ekowati, H. Rahmani, E.P.N. and Rastuti, U., 201I, The Active Fraction From Nigella sativa and its activity against T47D cell line, Indonesian Journal of Chemistry., I I (3), 2I7-222.

Gao, J. Lauer, F.T. Mitchell, L.A. and Burchiell, S.W., 2007, Microsomal Expoxide Hydrolase Is Required for 7,12Dimethylbenz[a]anthracene (DMBA)Induced Immunotoxicity in Mice, Toxicological Sciences., 98(I), I37-I44.

Gilani, A.H. Jabeen, Q. and Khan, M.A.U., 2004, A Review of Medicinal Uses and Pharmacological Activities ofNigella Sativa, Pakistan Journal of Biological Sciences., 7(4), 44|-45I.

Golstein, P. and Kroemer, G., 2006, Cell death by necrosis: towards a molecular definition, Trends Biochem Sci., 32, 3743.

Hanahan, D. and Weinberg, R.A., 20II, Hallmarks of Cancer: The Next Generation, Cell, I44, 646-7.

Hermawan, A., Murwanti, R., Artanti, N. and Meiyanto, E., 20II, Effect of the water extract of Macrosolen cochinchinensis (Lour.) Tiegh.leaves on 7, 12-Dimethylbenz[a]antracene induced female mice liver carcinogensis, Journal of Chinese Pharmaceutical Sciences, 6, 627-632

llaiyaraja, N. and Khanum, F., 2010, Nigella Sativa L. A Review of Therapeutic Applications, Journal of Herbal Medicine and Toxicology, 4(2), I-8.

Ivankovic, S. Stojkovic, R. Jukic, M. Milos, M. and Jurin, M., 2006, The antitumor activity of thymoquinone and thymohydroquinone in vitro and in vivo, Experimental Oncology, 28(3), 220-224.

Murray, R.K., Granner, D.K. and Rodwell, V.W., 2006, Biokimia Harper. Jakarta: Penerbit Buku Kedokteran EGC (In Indonesia).

Patri, M., Padmini, A., and Babu, P., 2009, Polycyclic aromatic hydrocarbons in air and their neurotoxic potency in 
association with oxidative stress: A brief perspective, Annals of Neuroscience, 16, 340-349.

Pich, A., Margaria, E., Chiusa, L., Bortolin, P. and Palestro, G., 2003, Relationship between AgNORs, MIB-I and OncogeneExpression in Male Breast Carcinoma and Papillary Superficial Bladder Neoplasm, Oncology Reports, 10, I329-1335.

Rajapaksa, K.S., Sipes, I.G. and Hoyer, P.B., 2007, Involvement of Microsomal Epoxide Hydrolase Enzyme in Ovotoxicity Caused by 7,12Dimethylbenz $[a]$ anthracene, Toxicological Sciences, 96(2), 327-334.

Rizali, E. and Auerkari, E.I., 2003, Teknik Pewarnaan Silver (AgNOR) Sebagai Salah Satu Cara Menentukan Aktivitas Proliferasi Sel Tumor dan Apoptosis,
Jurnal Kedokteran Gigi Indonesia, I0(3), $4 \mid-45$.

Shimada, T. and Guengerich, F.P., 2006, Inhibition of Human Cytochrome P450 $|A|-, \quad \mid A 2-, \quad$ and $|B|-M e d i a t e d$ Activation of Procarcinogens to Genotoxic Metabolites by Polycyclic Aromatic Hydrocarbons, Chem Res Toxicol., 19, 288-294.

Syazana, M.S.N., Halim, A.S., Gan, S.H. and Shamsuddin, S., 20II, Antiproliferative effect of methanolic extraction of tualang honey on human keloid fibroblasts, BMC Complementary and Alternative Medicine, I I (82), 472-482.

Yazan, L.S., Ng, W.K., Al-Naqeeb, G. and Ismail, M., 2009, Cytotoxicity of Thymoquinone (TQ) from Nigella sativa Towards Human Cervical Carcinoma Cells (HeLa), Journal of Pharmacy Research, 2(4), 585-589. 